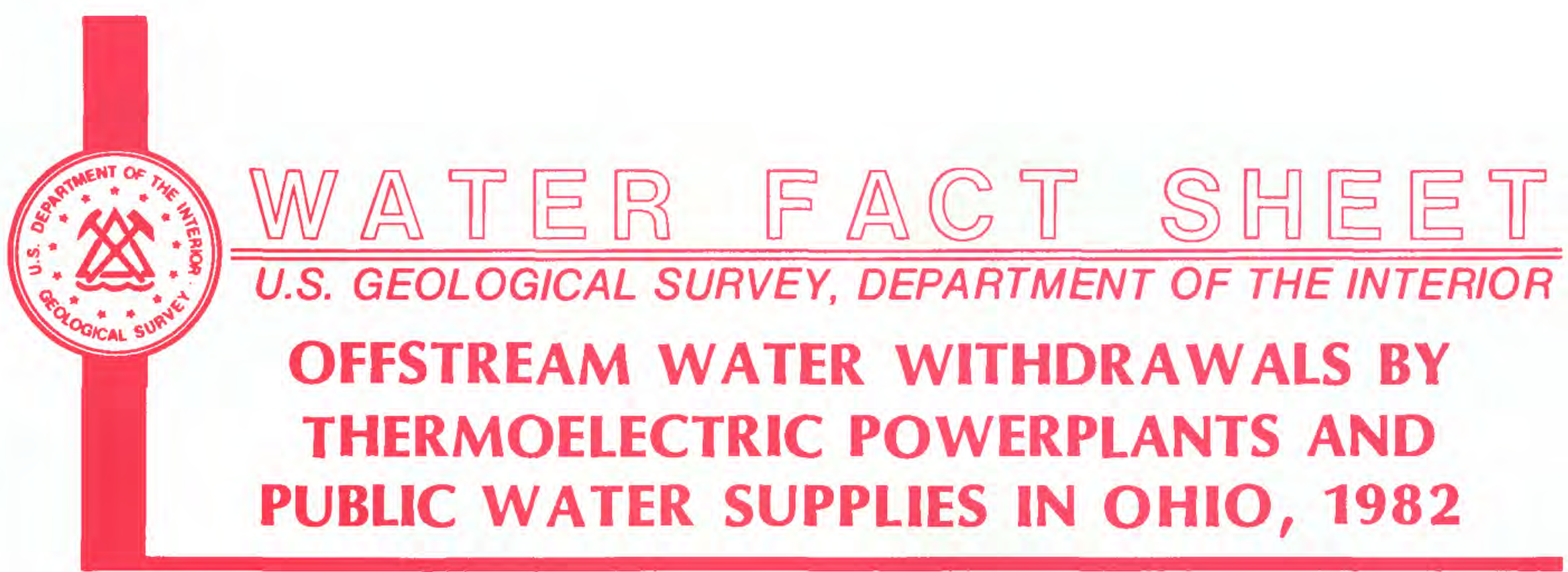

\title{
BACKGROUND
}

The U.S. Geological Survey and the Ohio Department of Natural Resources, Division of Water, have collected and published water-use data for Ohio since the early 1950's. In 1978, these two agencies combined their efforts to expand Ohio's water-use data activities through the National Water-Use Information Program. This Federal-State Cooperative Program to collect, store, and disseminate water-use information complements long-term U.S. Geological Survey data on the availability and quality of the Nation's water resources (Mann and others, 1982).

Ohio water-use data for 1980 are included in a National water-use report by Solley and others (1983), and are presented on a county-by-county basis by Eberle and McClure (1984). This fact sheet supplements the latter report with a summary of 1982 offstream waterwithdrawal data for thermoelectric (steam generating) power-plants and public water supplies because these were the two largest categories of withdrawals in Ohio in 1980 (Eberle and McClure, 1984): Together, they accounted for 86 percent of Ohio's total withdrawal use.

\section{WITHDRAWALS BY THERMOELECTRIC} POWERPLANTS

Thermoelectric powerplants require large amounts of cooling water to dissipate waste heat. Withdrawals by Ohio thermoelectric plants in 1982 totalled 9,700 million gallons per day (Mgal/d) compared with 10,000 $\mathrm{Mgal} / \mathrm{d}$ in 1980 . Totals by county for 1982 are shown in figure 1. Gallia County showed the largest increase (from $1,100 \mathrm{Mgal} / \mathrm{d}$ in 1980 to $1,200 \mathrm{Mgal} / \mathrm{d}$ in 1982), whereas Cuyahoga County showed the largest decrease (from $410 \mathrm{Mgal} / \mathrm{d}$ to $230 \mathrm{Mgal} / \mathrm{d}$ ).

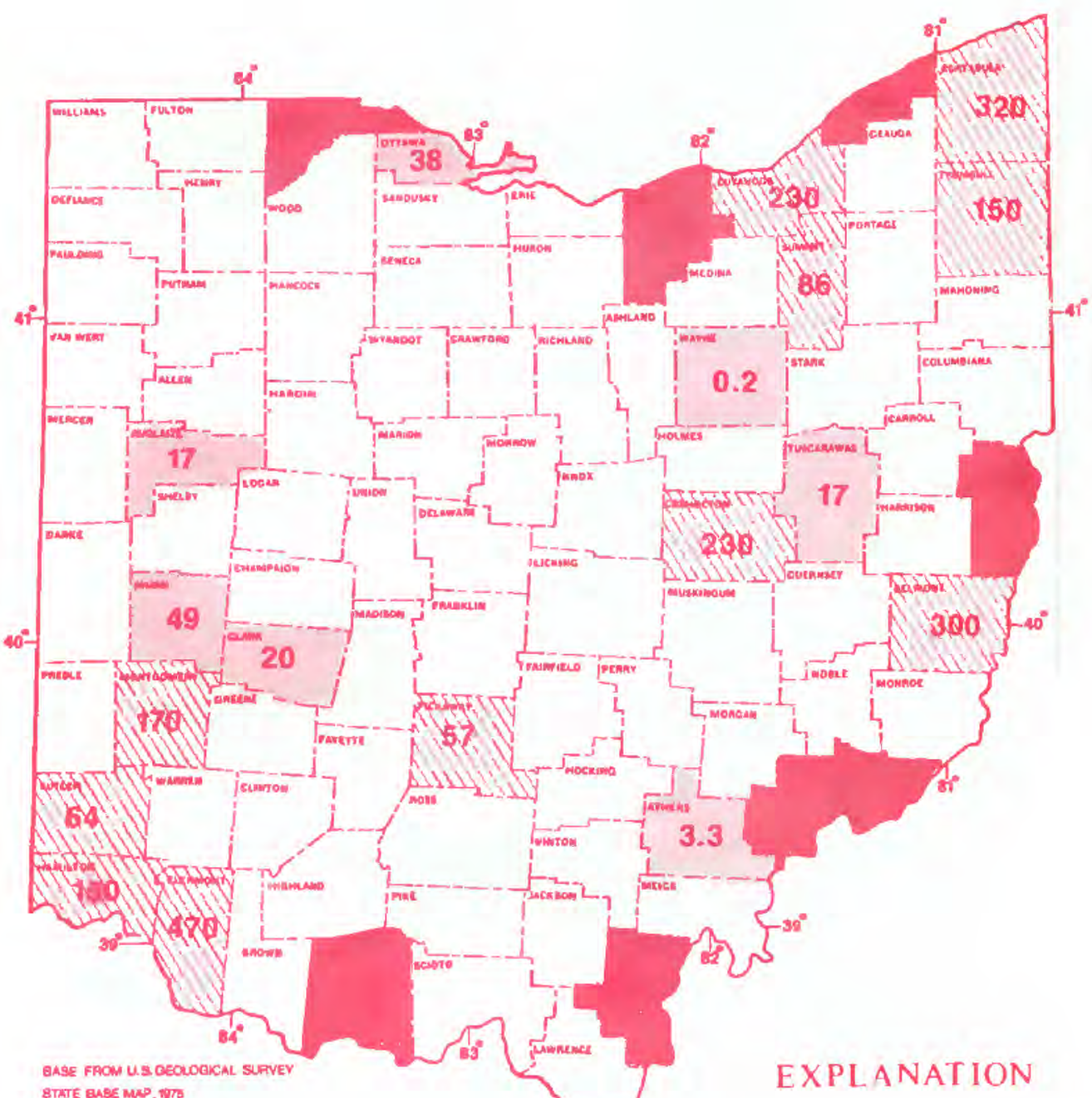

(million galtons per day)

Oㄴㄷㄴ $20 \quad 39 \quad 0$ MILES

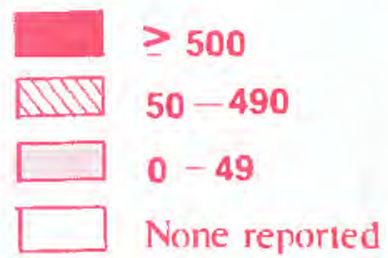

Numbers within count boun daries are totals rounded to two places

Figure 1. Offstream water withdrawal in 1982 , by county, for thermoelectric power generation for the 24 counties in Ohio with active thermoclectric plants. 


\section{WITHDRAWALS BY PUBLIC WATER SUPPLIES}

Public water supplies in Ohio are defined as water systems that have at least 15 service connections or serve at least 25 people year round. Offstream withdrawals for public water supplies in 1982 totalled 1,600 Mgal/d compared with $1,400 \mathrm{Mgal} / \mathrm{d}$ in 1980 . Totals by county are shown in figure 2. Trumbull County showed the largest increase (from $61 \mathrm{Mgal} / \mathrm{d}$ in 1980 to $100 \mathrm{Mgal} / \mathrm{d}$ in 1982), whereas Lucas County showed the largest decrease (from $87 \mathrm{Mgal} / \mathrm{d}$ to $82 \mathrm{Mgal} / \mathrm{d}$ ).

\section{SOURCES OF ADDITIONAL INFORMATION}

Additional information on water withdrawals in Ohio in 1980 and 1982 may be obtained by contacting:

\section{U.S. Geological Survey}

$975 \mathrm{~W}$. Third Avenue

Columbus, Ohio 43212

(614) 469-5553

Information about the National Water-Use Information Program and its computer data base, the National Water-Use Data System (NWUDS), may be obtained from the above office or from:

\section{National Water-Use Information Program \\ U.S. Geological Survey \\ 440 National Center \\ Reston, Virginia 22092 \\ (703) $860-6878$}

\section{REFERENCES CITED}

Eberle, Michael, and McClure, J.A., 1984, Water use in Ohio, 1980: U.S. Geological Survey Water-Resources Investigations Report 84-4024, 34 p.

Mann, W.B., IV, Moore, J.E., and Chase, E.B., 1982, A national water-use program: U.S. Geological Survey Open-File Report $82-862,12 \mathrm{p}$.

Solley, W.B., Chase, E.B., and Mann, W.B., IV, 1983, Estimated use of water in the United States in 1980: U.S. Geological Survey Circular 1001, 56 p.

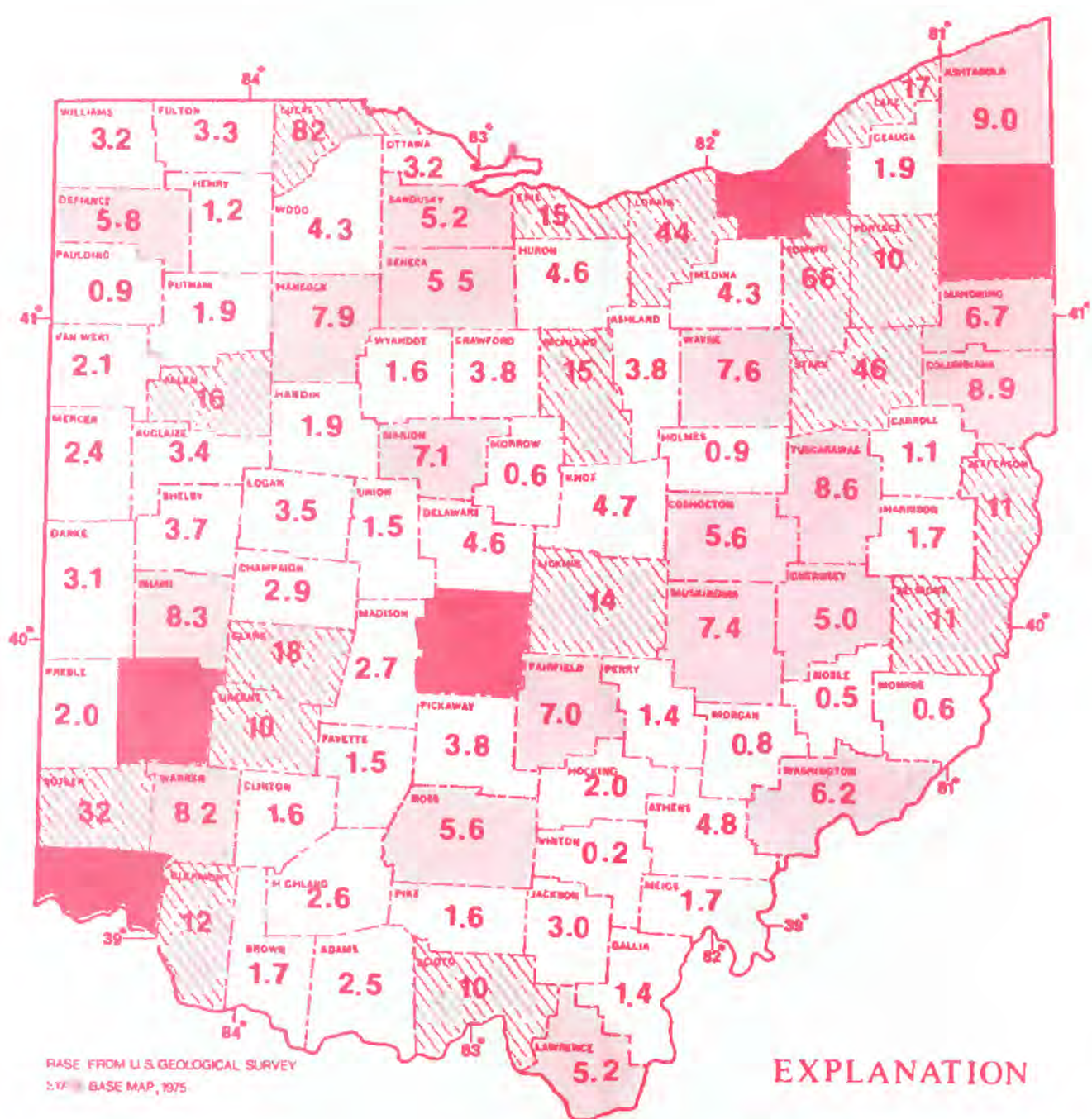

(miltion gallons per day)
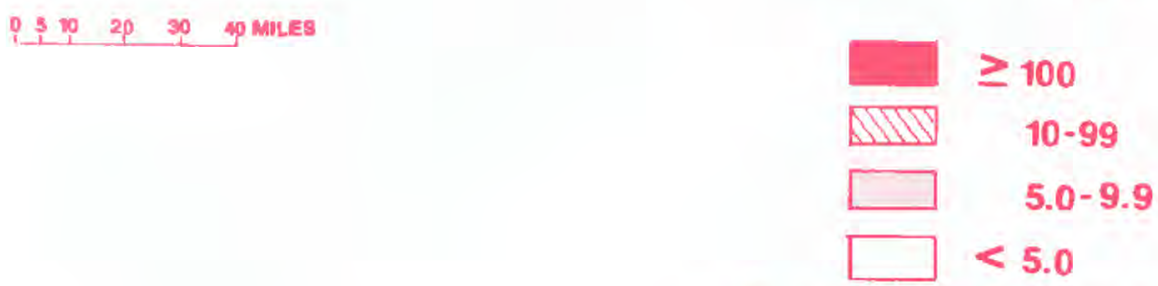

Numbers within county boundaries are totals rounded to two places

Figure 2 Offstream water withdrawals in 1982 , by county, for public water supplies. 